ційними ознаками лінгвотерапевтичності й сугестивності. Залишається відкритим питання щодо обсягу українського фразеологічного мінімуму, що $є$ перспективою подальших наукових розвідок.

\title{
Література:
}

1. Баран Я.А., Зимомря М.І., Білоус О.М., Зимомря I.М. Фразеологія: Знакові величини. Вінниця: Нова книга, 2008. 255 с.

2. Кузь Г. До проблеми формування фразеологічного мінімуму. Теорія і практика викладання української мови як іноземної. 2013. Вип. 8. С. 122-129.

DOI https://doi.org/10.30525/978-9934-588-80-8-2.14

\section{ЦИФРОВИЙ ПОСТУП ЗАКЛАДІВ ЗАГАЛЬНОЇ СЕРЕДНЬОЇ ОСВІТИ УКРАЇНИ}

\author{
Литвинова С. Г. \\ доктор педагогічних наук, старший науковий співробітник, \\ заступник директора з наукової роботи \\ Інститут інформачійних технологій $і$ засобів навчання \\ Національної академії педагогічних наук України \\ м. Київ, Украӥна
}

Широкомасштабне впровадження цифрових технологій в закладах загальної середньої освіти (3ЗСО) України відбувалося в три етапи (рис. 1.):

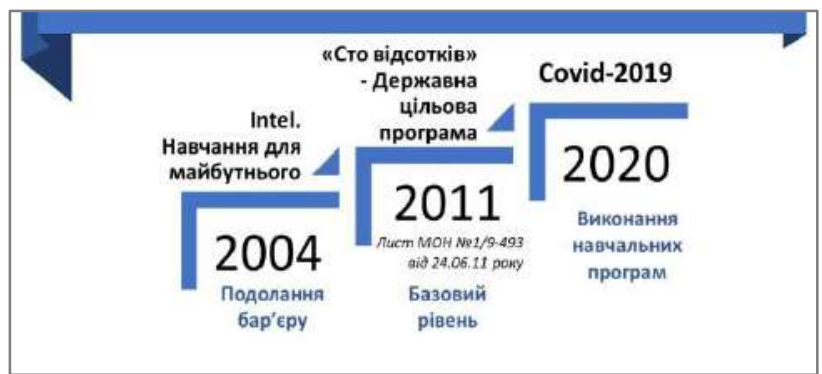

Рис. 1. Широкомасштабне впровадження цифрових технологій в школах України 
Периий етаn - згідно з програмою Intel. Навчання для майбутнього в системі післядипломної педагогічної освіти було організовано тижневі тренінги для педагогів з опанування проєктної методики та подолання бар'єру між вчителем і комп’ютером.

Другий етап - реалізація Державної цільової програми «Сто відсотків» та заходів, визначених листом МОН України № 1/9-493 від 24.06.11 року щодо підвищення інформаційно-комунікаційної компетентності вчителів, які були реалізовані управліннями освіти та інститутами післядипломної педагогічної освіти. В основі підвищення цифрової компетентності вчителів було використання базових сервісів: Word, Excel, PowerPoint та електронної пошти.

Tpemiŭ eman - Covid-2019. Це був шок для всієї освітньої галузі, та вчителів зокрема. Учителі пройшли 5 етапів сприйняття пандемії (за класифікацією Елізабет Кюблер-Росс) та нової форми навчання учнів (рис. 2).

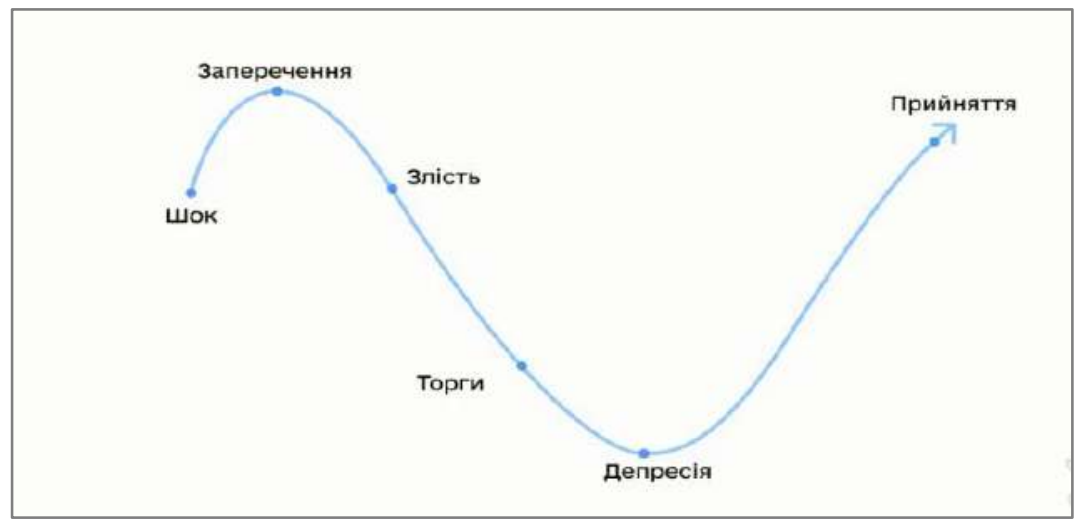

\section{Рис. 2. Сприйняття пандемії учителями за класифікацією Е. Кюблер-Росс}

Під час довготривалого карантину вчителі мали самостійно опановувати низку сервісів для виконання навчальних програм в умовах дистанційної форми навчання. Ми можемо класифікувати використані вчителями сервіси за категоріями (табл. 1). 
Таблиця 1

Категорії застосування сервісів в $33 \mathrm{CO}$

\begin{tabular}{|c|c|}
\hline Категорія & Сервіси \\
\hline Лекція (онлайновий урок) & $\begin{array}{c}\text { ZOOM, Skype, Google Meet, } \\
\text { Microsoft Teams }\end{array}$ \\
\hline Лабораторна або практична робота & Phet, CK-12.org, YouTube \\
\hline Контроль знань & $\begin{array}{c}\text { Google Forms, Microsoft Forms, } \\
\text { Plickers, Kahoot }\end{array}$ \\
\hline Комунікація & $\begin{array}{c}\text { e-mail, Viber, Telegram, } \\
\text { Facebook, Instagram }\end{array}$ \\
\hline
\end{tabular}

Аналізуючи потребу вчителів у забезпеченні освітнього процесу, новими навичками для них були:

- опанування сервісів відеозв'язку для проведення уроку-лекції;

- опанування сервісів для організації та проведення лабораторних і практичних робіт.

Частково вчителі були ознайомлені 3 технологією проведення онлайнових тестів. Не дивлячись на те, що вчителі вже мали досвід 3 використання сервісів комунікації, проблемою було формування бази номерів мобільних телефонів та електронних скриньок учнів.

Тому концептуальними підходами до реалізації дистанційної форми навчання в закладах загальної середньої освіти мають бути:

- єдина політика закладу освіти щодо формування цифрового освітнього середовища, яка може коригуватися для трьох рівнів здобуття загальної середньої освіти (початкова школа, гімназії, ліцеї);

- визначений перелік цифрових сервісів і додатків, що використовуватимуться в освітньому процесі у розрізі предметів;

- випереджальне планування освітньої діяльності: на початок навчального року має бути усвідомлено, що підготовку потрібно здійснювати заздалегідь - на чверть (добір презентацій, відео, комп'ютерних моделей, тестів);

- мікронавчання педагогів, учнів, батьків.

\section{Література:}

1. Pinchuk O., Burov O., Lytvynova S. Learning as a Systemic. Advances in Human Factors in Training, Education, and Learning Sciences. Advances in Intelligent Systems and Computing, 2019. Vol. 963. Pp. 335-342. https://doi.org/10.1007/978-3-030-20135-7_33. 